\title{
Integrating 3D photogeology with aeromagnetic data as a tool for base-metal exploration in East Greenland
}

\author{
Anaïs Brethes, Pierpaolo Guarnieri and Thorkild M. Rasmussen
}

An $800 \mathrm{~km}$ long basin system developed along the East Greenland margin since the Late Palaeozoic in which the Jameson Land Basin forms the southern part of the system. Along the margins of the Jameson Land Basin there are occurrences of barite, copper, lead, zinc and silver, which are particularly abundant in the northern part of the basin's eastern margin in the Wegener Halvø area (Fig. 1). Structures and stratigraphic architecture play important roles in the mineralisation distribution, so detailed mapping is essential. We used 3D photogeology combined with geophysical data to map the different stratigraphic units, faults and dykes in three dimensions.

\section{Geological setting of Jameson Land Basin}

The East Greenland Basin began to develop during the Devonian following the Caledonian orogeny. In the Late Carboniferous and Early Permian rotational block faulting took place (Surlyk 1990). The faults were reactivated during the Late Permian and Early Triassic and synsedimentary faulting occurred at the same time (Seidler 2000). The resulting fault blocks were peneplained before transgression and onset of sedimentation in the Late Permian. On Wegener Halvø the up to $300 \mathrm{~m}$ thick Upper Permian sequence unconformably overlies deformed and peneplained Devonian sediments (Fig. 1). The sequence is dominated by karstified dolomitic limestone of the Karstryggen Formation, by carbonate buildups which developed on palaeotopographic highs (the Wegener Halvø Formation) and by bituminous dark shale of the Upper Permian Ravnefjeld Formation. These filled up the deepest and karstified parts of the previous formations and locally contain calcareous concretions and fossils derived from the carbonate buildups. The unconformable to conformable Permian-Triassic boundary is locally incised by submarine canyons (Seidler 2000). Laterally variable, the Triassic stratigraphic architecture was controlled by tectonics and rapid asymmetric subsidence. This entire sequence is mainly composed of continental deposits with some shallow marine incursions. In the Tertiary the Jameson Land Basin was covered by flood basalt and intruded by a complex of sills and E-W to NW-SE-trending dykes. The intrusions that are dated to the latest Paleocene to earliest Eocene (Soper $e t$ al. 1976) affect the entire sequence of basin fill. In Miocene time the northern part of the basin was uplifted more than $1 \mathrm{~km}$ (Mathiesen et al. 2000; Hansen et al. 2001).

\section{Base-metal mineralisation on Wegener Halvø}

The first rock samples were collected in East Greenland in 1822 and during the Three-year Expedition to East Greenland from 1931 to 1934 copper-, lead- and silver-bearing minerals were discovered on Wegener Halvø (Fig. 1), in the Upper Permian carbonates of the Wegener Halvø Formation. Subsequent investigations by Nordisk Mineselskab A/S (Nordmine) led to the discovery in 1968 of base-metal occurrences in the black shale of the Ravnefjeld Formation. Min-

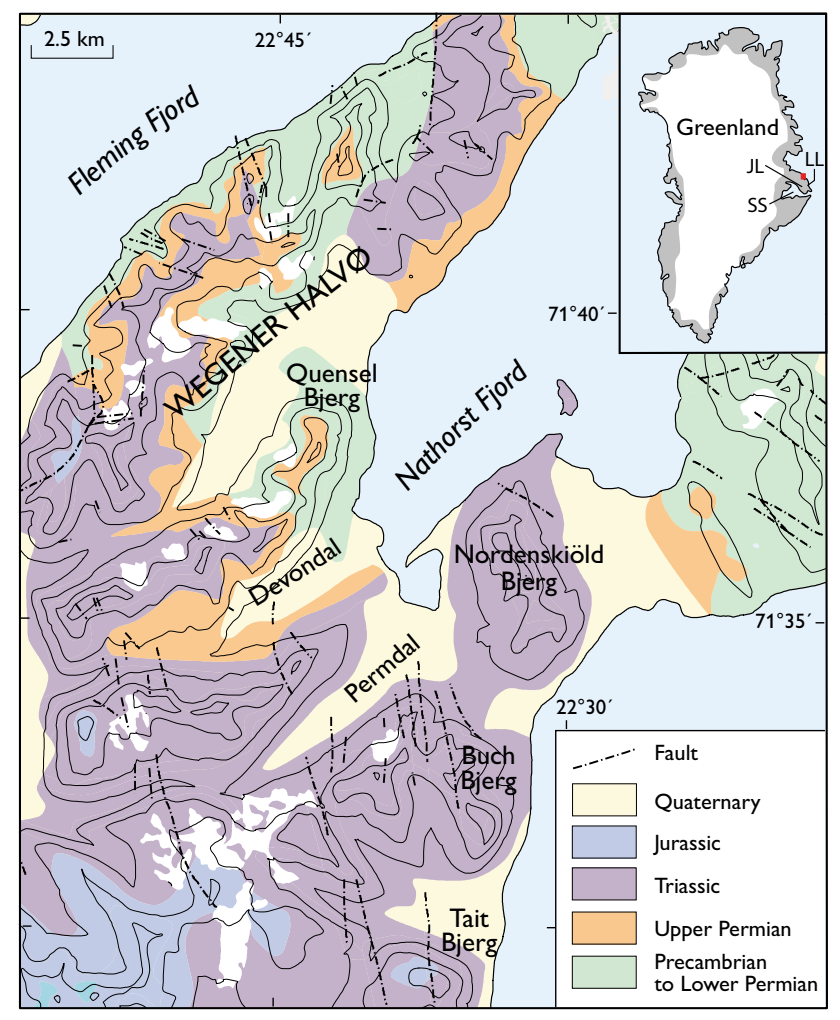

Fig. 1. Simplified geological map of the Wegener Halvø area (modified from Perch-Nielsen et al. 1983). SS: Scoresby Sund. JL: Jameson Land. LL: Liverpool Land. Contour interval $200 \mathrm{~m}$. 


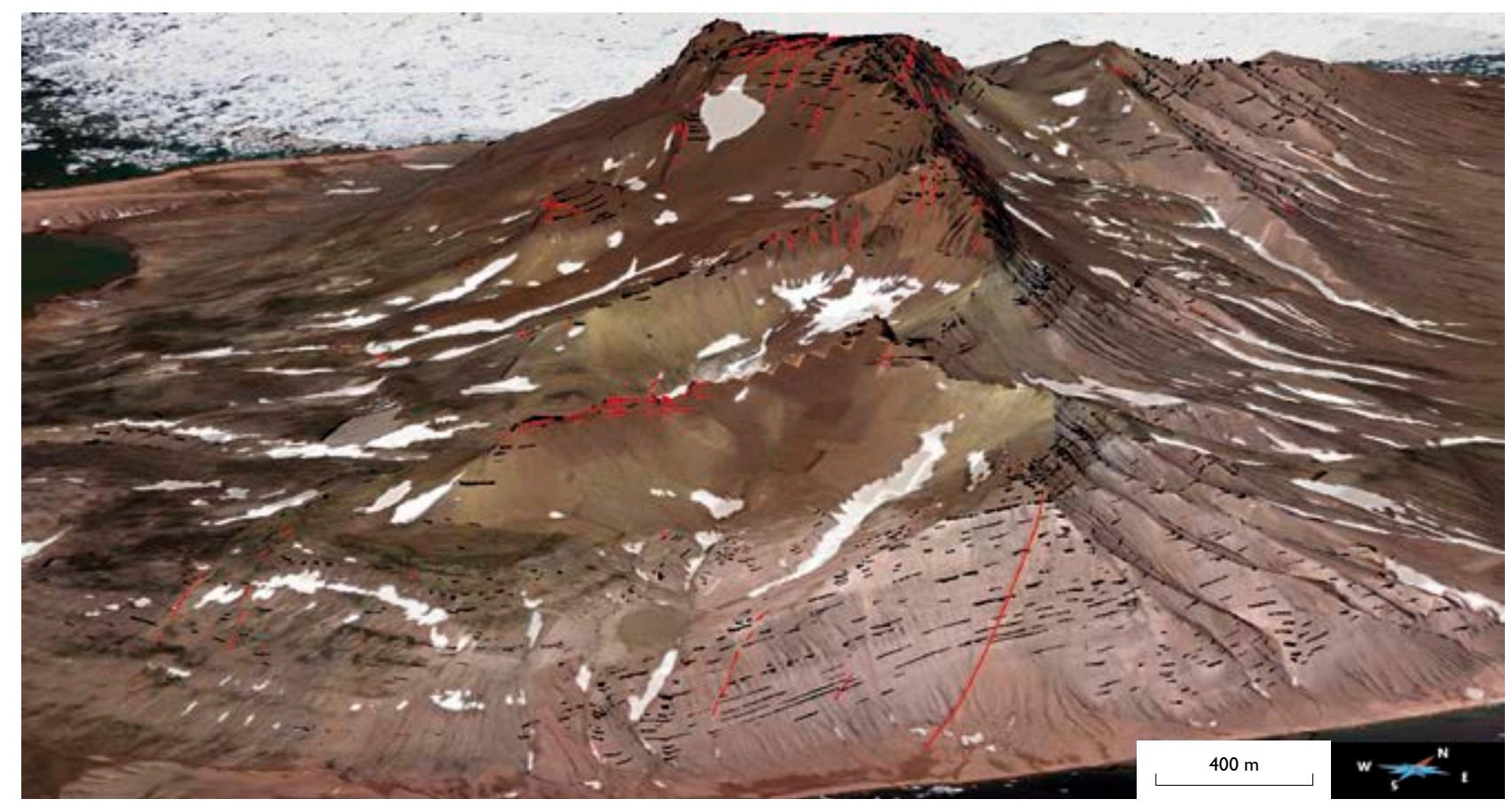

Fig. 2. 3D view from the south towards Nordenskiöld Bjerg created with orthophotographs draped on a digital elevation model developed from LIDAR data. The geological features collected from aerial photographs are: faults and fractures (red lines) and Triassic bedding (black lines).

eral exploration ceased because the ore was too low grade, but the oil industry became interested in the hydrocarbon source-rock potential of the Upper Permian shale. Harpøth et al. (1986) reviewed more than a century of these sporadic field campaigns and since 2011 Avannaa Resources Ltd has explored the area for base metals. Mineral occurrences are particularly abundant along the eastern margin of the Jameson Land Basin, especially in the Wegener Halvø area where they occur in three of the Upper Permian formations and three of the Triassic formations. One of the most interesting ore-bearing formations is the limestone buildups of the Wegener Halvø Formation. As described by Harpøth et al. (1986), $\mathrm{Cu}, \mathrm{Pb}$ and $\mathrm{Zn}$ sulphides are scattered throughout the whole peninsula. They are also found as fine-grained material in inter-reef black-shale occurrences in the Ravnefjeld Formation. Base-metal minerals are mainly found in the upper part of the carbonates and in the lower part of the shales (Upper Permian formations), but stratiform occurrences occur in Triassic sediments. Early Triassic alluvial conglomerate and arkosic sandstone are mineralised with argentiferous chalcocite-covellite, and galena occurs as cement. According to soil sample geochemical analyses, the highest grades appear to be concentrated at the contact between two facies, in a trend perpendicular to the palaeocurrents (Harpøth $e t$ al. 1986). In the Late Triassic playa-lake mudstone and sandstone, fine-grained $\mathrm{Cu}$ sulphides are found over an area of $1000 \mathrm{~km}^{2}$.

\section{D photogeology}

The Geological Survey of Denmark and Greenland is equipped with a $3 \mathrm{D}$ stereoplotter to carry out multi-model photogrammetry that can be used to accurately map geological features from vertical and oblique aerial photographs. The instrument is equipped with two polarised monitors set one above the other with an angle of $110^{\circ}$ separated by a halfmirror (Vosgerau et al. 2010). Each polarised screen displays one photograph of an overlapping stereopair. The half-mirror allows the viewer to see two photographs as one image with $3 \mathrm{D}$ polarised glasses getting a depth perception of the geological features that, in turn, can be digitised as $3 \mathrm{D}$ polylines. The geologic features and the database are automatically imported into a geographic information system where they can be edited. The photographs used for the present work were taken during a combined hyperspectral and LIDAR survey in 2012 (Thorning et al. in press). The spacing between the flight lines was $c .500 \mathrm{~m}$ and the pixel size in the centre of each image is $27 \times 27 \mathrm{~cm}$.

On Wegener Halvø, an area of $100 \mathrm{~km}^{2}$ comprising Devondal and Nordenskiöld Bjerg was mapped on a scale of 1:1000 (Fig. 1). More than 5000 features were digitised, including bedding, stratigraphic boundaries as well as fractures and dykes (Fig. 2). Together with the digitised 3D polylines it is possible to calculate strata thicknesses and measure strike and dip of bedding of faults and dykes. The overall 
stratigraphic succession is based on the published geological map (Perch-Nielsen et al. 1983). More than 900 faults, fractures and dykes were digitised in the Wegener Halvø area and the majority shows a N-S and NNW-SSE-orientation. The structures are steep and occur as flower structures affecting the entire succession. The vertical offset is small and decreases from south to north along the strike of the faults that in some cases have a strike-slip component.

\section{Integrated 3D photogeology and aeromagnetic data}

The dataset from the interpretation of the photographs has been combined with a new structural interpretation of airborne magnetic data from the AEM Greenland 1997 survey (Rasmussen et al. 2001). Different maps were obtained from the calculation of the magnetic gradient tensor elements to highlight structures in different directions (Pedersen \& Rasmussen 1990). The total magnetic intensity anomalies of the structures of interest have small amplitudes (around $3 \mathrm{nT}$ ) that are close to the detection limit of c. $0.5 \mathrm{nT}$ of an airborne survey. As differentiation works as a high-pass filter, the second vertical derivative of the total magnetic intensity was also calculated to emphasise the linear features. This processing provides a better dynamic range for visualising the structures than the measured field. To attenuate the short wavelength noise features generated by this differentiation, an upward continuation of the magnetic field to $100 \mathrm{~m}$ was applied. Lineaments defined by negative magnetic anomalies and interpreted as major structures were digitised on the resulting map (Fig. 3A). These features are $\mathrm{N}-\mathrm{S}$ to NNW-SSE-trending and several kilometres long and they fit with the faults in the geological map (Fig. 1) and with the fault segments mapped with the 3D stereo-plotter (Fig. 3B). The accurate fault segments mapped by photogeology were integrated with the magnetic lineaments highlighted at a larger scale. Thus, an identified structure can be prolongated on the map using geophysical data and constrained in its precise location and dip using 3D photogeology. One of the $\mathrm{N}-\mathrm{S}$-trending faults mapped by $3 \mathrm{D}$ photogeology and visible on the magnetic data coincides with the so-called Vimmelskaft lineament defined by Pedersen (1997). This lineament corresponds to a zone where a $\mathrm{N}-\mathrm{S}$-trending fault and a $\mathrm{N}-\mathrm{S}$-running dyke cut through Upper Permian shales and karstified carbonates. Important mineral occurrences with high base-metal content are found along this lineament and the concentration decreases away from the lineament.
Fig. 3. A: Second vertical derivative of the total magnetic intensity (TMI) from the AEM Greenland 1997 survey (pixel size is $50 \times 50 \mathrm{~m}$ ) continued upward to $100 \mathrm{~m}$ and draped on the shaded elevation model. The negative magnetic lineaments are digitised and shown as black lines. B: Correlation between magnetic data and the faults, fractures and bedding collected from aerial photographs. Note the presence of eroded strata parallel to positive magnetic anomalies and faults and fractures related to negative anomalies.
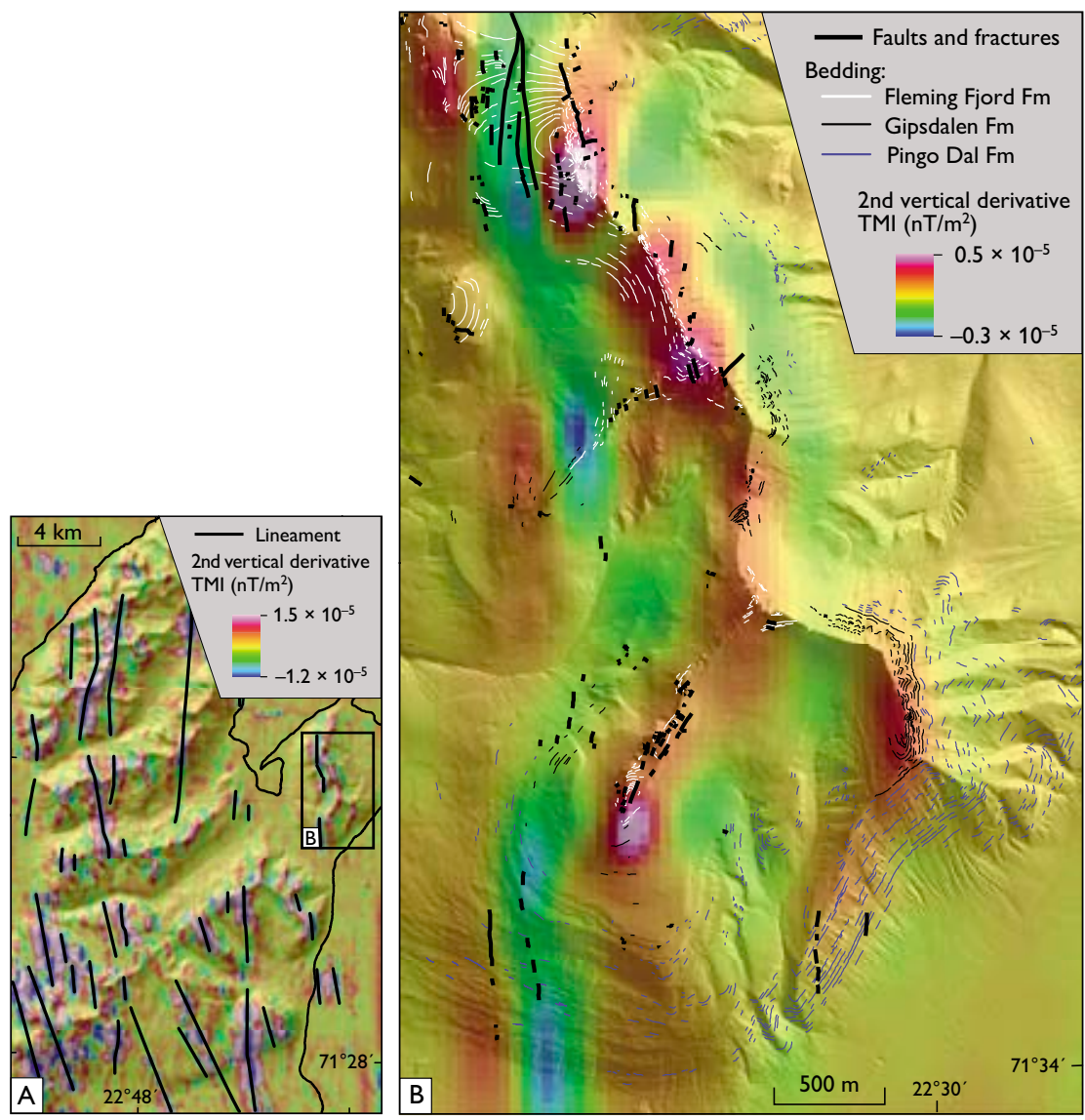
The positive magnetic anomalies are not linear and appear to be associated with magnetic domains in the Triassic formations (Fig. 3B). The contours of these domains are parallel to the stratification collected from 3D photogeology (edges of eroded beds) and are mostly located on crests.

\section{Concluding remarks}

Using 3D photogeology we mapped a $100 \mathrm{~km}^{2}$ area with good exposures on a scale of 1:1000. Formation boundaries and dip of strata are well constrained. New structures were mapped and the resulting dataset forms a good starting point for further studies of the stratigraphy or tectonic evolution using 3D modelling. The combination of 3D photogeology with new processing of the magnetic data has shown a good match between $\mathrm{N}-\mathrm{S}$-trending magnetic lineaments and $\mathrm{N}-\mathrm{S}$-trending normal steep faults. Structures of this type were highlighted by Pedersen (1997) for their possible role as pathways for mineralising fluids. The structures mapped during this study that affect the Upper Permian carbonates and shales, should be checked in the field. Furthermore, although mineral occurrences found in the Triassic formations are stratiform, remobilised sulphides are concentrated in cross-cutting fractures. The mapped faults and fractures that cut through Triassic formations could also be interesting targets for exploration. Detailed studies of structures and stratigraphic architecture are key points for mineral exploration. Accurate mapping using 3D photogeology combined with geophysical data can be efficient tools for this, especially in areas with difficult access and excellent outcrops.

\section{References}

Hansen, K., Bergman, S.C. \& Henk, B. 2001: The Jameson Land ba$\sin$ (east Greenland): a fission track study of the tectonic and thermal evolution in the Cenozoic North Atlantic spreading regime. Tectonophysics 331, 307-339.

Harpøth, O., Pedersen, J.L., Schønwandt, H.K. \& Thomassen, B. 1986: The mineral occurrences of central East Greenland. Meddelelser om Grønland, Geoscience 17, 139 pp.
Mathiesen, A., Bidstrup, T. \& Christiansen, F.G. 2000: Denudation and uplift history of the Jameson Land basin, East Greenland constrained from maturity and apatite fission track data. Global and Planetary Change 24, 275-301.

Pedersen, M. 1997: Investigation of ore potential in black shales of the Upper Permian Ravnefjeld Formation in Scoresby Land and on Traill Ø, central East Greenland. Danmarks og Grønlands Geologiske Undersøgelse Rapport 1997/124, 17 pp.

Pedersen, L.B. \& Rasmussen, T.M. 1990: The gradient tensor of potential field anomalies. Some implications on data collection and data processing of maps. Geophysics 55, 1558-1566.

Perch-Nielsen, K., Henriksen N. \& Stemmerik, L. 1983: Geological map of Greenland, 1:100 000, Fleming Fjord, $71 \varnothing .1$ Nord. Copenhagen: Geological Survey of Greenland.

Rasmussen, T.M., Thorning, L., Stemp, R.W., Jørgensen, M.S. \& Schjøth, F. 2001: AEM Greenland 1994-1998 - summary report. Danmarks og Grønlands Geologiske Undersøgelse Rapport 2001/58, 46 pp.

Seidler, L. 2000: Incised submarine canyons governing new evidence of Early Triassic rifting in East Greenland. Palaeogeography, Palaeoclimatology, Palaeoecology 161, 267-293.

Soper, N.J., Downie, C., Higgins, A.C. \& Costa, L.I. 1976: Biostratigraphic ages of Tertiary basalts on the East Greenland continental margin and their relationship to plate separation in the Northeast Atlantic. Earth and Planetary Science Letters 32, 149-157.

Surlyk, F. 1990: Timing, style and sedimentary evolution of Late Palaeozoic - Mesozoic extensional basins of East Greenland. In: Hardman, R.F.P. \& Brooks, J. (eds): Tectonic events responsible for Britain's oil and gas reserves. Geological Society, Special Publication (London) 55, 107-125.

Thorning, L., Christensen, N.N., Olsen, S., Riisager, P., Sørensen, L.L., Sørensen, E.V. \& Tukiainen, T. in press: High resolution airborne hyperspectral imaging spectroscopy in central East Greenland 2012 - data acquisition and pre-processing. Danmarks og Grønlands Geologiske Undersøgelse Rapport.

Vosgerau H., Guarnieri P., Weibel R., Larsen M., Dennehy, C., Sørensen, E.V. \& Knudsen, C. 2010: Study of a Palaeogene intrabasaltic sedimentary unit in southern East Greenland: from 3-D photogeology to micropetrography. Geological Survey of Denmark and Greenland Bulletin 20,75-78.

\footnotetext{
Authors' addresses

A.B. \& P.G., Geological Survey of Denmark and Greenland, Øster Voldgade 10,DK-1350 Copenhagen K, Denmark. E-mail:aib@geus.dk

T.M.R., Division of Geosciences and Environmental Engineering, Lulea University of Technology, S-971 87 Luleå, Sweden.
} 